\title{
LA FIGURACIÓN MARGINAL EN LA BAJA EDAD MEDIA: TEMAS DEL «MUNDO AL REVÉS» EN LA MINIATURA DEL SIGLO XV*.
}

\author{
POR \\ FERNANDO GUTIÉRREZ BAÑOS \\ Universidad de Valladolid
}

This paper deals with figures on the margins of illuminated manuscripts from 15 th century. The study of a certain type of images, those related with the world upside-down, raises problems about the history of figures on the edge and about their significance. The history and character ot the world upside-down and several themes concerning it found in the margins of Flemish and French manuscripts, most of them now in Spanish libraries are discussed. So, hunters being hunted, unequal fights, domineering women or animals behaving against their nature are not seen as amusing or liberating items, but as worrying ones.

$\mathrm{Al}$ estudio iconográfico de la figuración marginal de los manuscritos iluminados bajomedievales, modernamente denominada drôlerie (extravagancia), se han dedicado importantes trabajos, siendo, tal vez, el más conocido el que publicara Randall en $1966{ }^{1}$, dedicado sólo a manuscritos de los siglos XIII y xIV, siglos que, por otra parte, constituyen un período homogéneo y cerrado en la historia de la figuración marginal, dejando a un lado su complejo desarrollo a partir de finales del siglo xIv. Pretendo, pues, realizar una aproximación al estudio de la figuración marginal del siglo xv. Para ello he revisado los márgenes de unos ochenta manuscritos de esa centuria y de comienzos de la siguiente conservados en la Biblioteca Nacional, en la Real Biblioteca de Palacio y en la Real Biblioteca del Monasterio de San Lorenzo de El Escorial seleccionados a partir del trabajo recopilatorio de Domínguez Bordona ${ }^{2}$, aunque tampoco he desaprovechado las referencias bibliográficas sobre algunos manuscritos conservados en bibliotecas extranjeras.

Dado este carácter de aproximación, me centraré tan sólo en el estudio de un grupo de temas,

* Este trabajo ha podido ser elaborado merced a una Beca de Introducción a la Investigación en Centros del Consejo Superior de Investigaciones Científicas de la que disfruté durante el año 1995 en el Departamento de Historia del Arte "Diego Velázquez» del Centro de Estudios Históricos, a todos los miembros del cual, y muy especialmente a Isabel Mateo, se lo dedico con afecto y agradecimiento. Asimismo quiero dejar constancia de mi agradecimiento a José Manuel Pedrosa y a Claudie Ressort.

1 Randall, Lilian M. C.: Images in the Margins of Gothic Manuscripts, University of California Press, Berkeley-Los Ángeles, 1966.

2 Domínguez Bordona, Jesús: Manuscritos con pinturas, Centro de Estudios Históricos, dos tomos, Madrid, 1933. 
relacionados con el tópico del mundo al revés. De entre la multitud de temas que aparecen en los márgenes de los manuscritos iluminados bajomedievales destacan aquellos que presentan situaciones grotescas y, muy especialmente, los que presentan imágenes adscribibles al tópico del «mundo al revés». Lejos de ser el producto de una especie de genio nacional de un área concreta, como pretendiera Maeterlinck en beneficio de Flandes ${ }^{3}$, estos temas, de antiguas raíces, son comunes a todo el área de la cultura occidental, como se pone de manifiesto en el hecho de que exista una expresión para el concepto de mundo al revés en todas las lenguas occidentales (world upside-down o topsy-turvey world en inglés, verkehrte Welt en alemán, monde à l'envers, au rebours o renversé en francés, mondo alla riversa o alla rovescia en italiano...) ${ }^{4}$, y tienen su correlato en diversas manifestaciones literarias como la fatrasie francesa, la frottola italiana o el más tardío disparate español, amén de resonancias en otros géneros ${ }^{5}$. Precisamente al amparo de este carácter internacional me he permitido utilizar para el estudio de algunas de las imágenes que aquí serán analizadas versos de composiciones burlescas españolas contemporáneas ${ }^{6}$ para destacar cómo estos temas fueron realmente comunes a todo el área de la cultura occidental y cómo las imágenes de estos manuscritos, en su totalidad flamencos o franceses, pudieron ser perfectamente comprendidas por sus poseedores españoles de los siglos XV y XVI, pues sin duda muchos de estos manuscritos ahora en bibliotecas españolas pertenecieron en su momento a miembros destacados de la nobleza y de la realeza de los reinos hispánicos ${ }^{7}$. Curiosamente, a pesar de haber tenido en cuenta manuscritos de todo tipo, todas las imágenes de las que aquí trataré están tomadas de márgenes de libros de horas, lo cual se debe sin duda, más que a razones textuales, a que estos manuscritos son los más abundantes y lujosos.

Me gustaría poder plantear aquí la problemática de la evolución de la figuración marginal a lo largo del siglo $\mathrm{xv}^{8}$, pero razones de concisión me obligan a centrarme en el estudio iconográfico propuesto. Así pues, espero que baste con recordar que, tras su eclosión, probablemente en Inglaterra, a mediados del siglo xil como consecuencia de una compleja conjunción de factores de muy diversa naturaleza ${ }^{9}$ y tras su brillante desarrollo en Inglaterra, en los Países Bajos y en Francia a lo largo de la segunda mitad del siglo xIII y de la primera mitad del siglo xIv, la figuración marginal entró en un período de zozobra del que sólo se recuperó en los años en torno a 1400, años de efervescencia en los que se produjo tanto el definitivo periclitar de la vieja tradición como el resurgir de la figuración marginal merced al aporte exterior, a la actividad en los ta-

3 Maeterlinck, L.: Le genre satirique dans la peinture flamande, $2^{\mathrm{a}}$ ed., Librairie Nationale d'Art et d'Histoire, G. van Oest \& Cie, Bruselas, 1907, p. 1.

4 Grant, Helen F.: "The World Upside-Down", en VV.AA.: Studies in Spanish Literature of the Golden Age presented to Edward M. Wilson, Tamesis Books, Londres, 1973, p. 103.

5 Sobre estas manifestaciones, véase Periñán, Blanca: Poeta ludens. Disparate, perqué y chiste en los siglos XVI y XVII, Giardini Editori e Stampatori, Pisa, 1979, pp. 23-26.

6 En especial me remitiré varias veces a una composición titulada Disparates muy graciosos que comienza: Caminando un Viernes Santo..., la cual en el siglo pasado fue incluida por Usoz en su edición del Cancionero de obras de burlas provocantes a risa, aunque en realidad nunca formó parte de la recopilación de Hernando del Castillo, sino que apareció en un pliego suelto del siglo xvi, a pesar de lo cual los modernos editores de este cancionero la han mantenido en dicha colección (Cancionero de obras de burlas provocantes a risa, edición de Juan Alfredo Bellón Cazabán y Pablo Jauralde Pou, Ediciones Akal, Madrid, 1974, núm. 77, pp. 268-272.

7 A este respecto, véanse Domínguez Rodríguez, Ana: Libros de horas del siglo XV en la Biblioteca Nacional, Fundación Universitaria Española, Madrid, 1979, pp. 78, 83 y 117 y Docampo, Javier: “Un libro de horas inédito: el ms. 21547 de la Biblioteca Nacional de España y sus miniaturas", A.E.A., tomo LXIX, Madrid, 1996, p. 70.

8 A Henry y a Lyna se deben sendas valiosas y apretadas síntesis sobre la evolución de la decoración marginal (Henry, Suzanne: "La décoration marginale française dans les manuscrits du milieu du XIII a la fin du xv ${ }^{\mathrm{e}}$ siècle", École Nationale des Chartes. Position des thèses, París, 1951, pp. 79-83; Lyna, Frédéric: "La bordure marginale dans les manuscrits flamands à l'époque gothique», Les Beaux-Arts, núm. especial, París, 1959, pp. 1 y 4).

9 Randall, Lilian M. C.: Images..., pp. 8-9; Camille, Michael: Image on the Edge. The Margins of Medieval Art, Reaktion Books, Londres, 1992, pp. 10, 18-24 y 151-152. 
lleres parisinos de un artista italiano excepcional, el denominado maestro de las Iniciales de Bruselas, que introdujo en los manuscritos en que trabajó una decoración marginal de raigambre italiana dominada por grandes hojas de acanto multicolor en torno a las cuales y en los medallones por ellas conformados dispuso motivos figurativos frecuentemente grotes$\cos { }^{10}$. Final y principio, los años en torno a 1400 fueron también años en los que, en la obra de los hermanos Limbourg en las Très Riches Heures del duque de Berry (Chantilly, Musée Condé, ms. 65), se plantearon algunas de las cuestiones que, a la postre, pusieron fin a la figuración marginal en poco menos de un siglo ${ }^{11}$, pero, por el momento, la resucitada figuración marginal triunfó en la miniatura francesa y, posteriormente, en la miniatura flamenca. Fue, precisamente, en este ámbito donde, sin embargo, se asestó uno de los primeros golpes de gracia a la vieja figuración marginal. A mediados de los años ochenta del siglo xv, el denominado a partir de los estudios de Pächt maestro de María de Borgoña revolucionó la decoración marginal de los manuscritos flamencos dando origen a la que Durrieu denominara escuela de Gante-Brujas ${ }^{12}$, caracterizada en cuanto a su decoración marginal por presentar sobre un fondo dorado uniforme mariposas, insectos, flores... en aparente y fortuita dispersión, reproducidos con tal precisión que parecen ser elementos reales caídos al azar sobre la página del manuscrito, cuya planitud de esta manera se cuestiona, rompiéndose así el tradicional equilibrio entre texto, miniatura y decoración marginal, a cuyo final contribuyeron también la difusión de la imprenta y el respeto por el texto propio de la cultura humanista ${ }^{13}$.

Junto a la problemática de la evolución de la figuración marginal desde el punto de vista externo y formal se encuentra la cuestión no menos vidriosa del carácter de la misma, donde se dan posiciones encontradas entre quienes defienden su carácter decorativo y quienes defienden su carácter significativo, coherente con el manuscrito que la contiene ${ }^{14}$, junto a posturas conciliadoras como la de Davenport, que desarrolla la idea de una conexión indirecta (oblique) entre texto y figuración marginal ${ }^{15}$. Personalmente, después de haber examinado cientos y cientos de márgenes de manuscritos del siglo xv, la conclusión a la que llego, de acuerdo, fundamentalmente, con Janson ${ }^{16}$, es que la figuración marginal tuvo, al menos en esta centuria, un carácter esencialmente decorativo (acorde, por recordar cierta afortunada observación hecha por Henry, con la "forma" más que con el "fondo" del manuscrito ${ }^{17}$ ) y una dimensión eminentemente visual, desligada del texto al que acompaña, lo cual no obsta para que sus temas tengan un claro contenido tomado del contexto cultural del momento y forjado por generaciones de tradición que ha-

10 Meiss, Millard: French Painting in the Time of Jean de Berry: The Late Fourteenth Century and the Patronage of the Duke, Phaidon Press \& Phaidon Publishers, Londres-Nueva York, 1967, p. 246; Calkins, Robert G.: "An Italian in Paris: The Master of the Brussels Initials and His Participation in the French Book Industry", Gesta, vol. XX, Nueva York, 1981 , pp. 223 y ss.

11 Meiss, Millard: French Painting in the Time of Jean de Berry: The Limbourgs and Their Contemporaries, Thames and Hudson y The Pierpont Morgan Library, Nueva York, 1974, pp. 178-181.

12 Durrieu, Paul: La miniature flamande au temps de la cour de Bourgogne (1415-1530), 2. ed., París-Bruselas, 1927, pp. 38-40.

13 Camille, Michael: Image..., pp. 157-158.

14 Sobre esta cuestión y sobre las posturas de distintos autores al respecto, véanse Randall, Lilian M. C.: "The Snail in Gothic Marginal Warfare», Speculum, vol. XXXVII, Cambridge (Mass.), 1962; p. 360, Davenport, S. K.: «Illustrations Direct and Oblique in the Margins of an Alexander Romance at Oxford", Journal of the Warburg and Courtauld Institutes, vol. XXXIV, Londres, 1971, p. 92; Camille, Michael: Image..., pp. 31-32; y Müller, Markus: «Fonctions du profane et du "ridiculum" dans l'enluminure médiévale", Histoire de l'Art, núm. 29-30, París, 1995, pp. 28 y 30.

15 Davenport, S. K.: “Illustrations...”, pp. 83-86, 89 y 94.

16 Janson, Horst W.: Apes and Ape Lore in the Middle Ages and the Renaissance, The Warburg Institute, Londres, 1952, pp. 163-164.

17 Henry, Suzanne: «La décoration marginale...», p. 79. 
ce de ellos merecedores de un estudio iconográfico como el que abordo en estas páginas, el cual carecería de sentido si se tratase de motivos meramente ornamentales ${ }^{18}$.

Volviendo sobre aquellos temas a través de los cuales efectuaré mi aproximación al estudio de la figuración marginal del siglo $\mathrm{XV}$, creo necesario hacer unas precisiones sobre el concepto de mundo al revés. Es éste un concepto de límites poco definidos que exige, más allá de una apariencia chocante, una inversión con respecto al orden natural de las cosas ${ }^{19}$. Quedan fuera de su ámbito aquellos motivos en que simplemente aparecen animales desarrollando comportamientos propios del ser humano, numerosos e interesantes, siempre y cuando no se dé en ellos este requisito de la inversión con respecto al orden natural de las cosas (así, por ejemplo, no considero dentro del tópico del mundo al revés aquella escena en la que un animal actúa como médico de otro animal, pero sí aquella en la que un animal actúa como médico de un hombre). Aunque bastante complejo, pueden bastar para definir el carácter del tópico del mundo al revés la ambigüedad inherente al mismo (moralizante, lúdico...) y el contexto cristiano en que necesariamente ha de comprenderse dentro de la cultura occidental, contexto en el que es fundamental la idea de un mundo creado por Dios en orden y en armonía cuya inversión sólo puede ser el resultado del pecado y de las fuerzas del mal ${ }^{20}$.

De la misma manera que el tópico del mundo al revés no es privativo de una determinada área, sino propio de todo el ámbito de la cultura occidental, tampoco es privativo de una determinada época de la misma, sino que se manifiesta a lo largo de todo su desarrollo en esferas específicas según el momento y con una naturaleza determinada. Esta vitalidad del tópico del mundo al revés es subrayada por Cocchiara ${ }^{21}$. Curtius, de acuerdo con su visión de la cultura occidental como un todo orgánico que arranca de Grecia y de Roma, sitúa el origen del tópico del mundo al revés en la antigua Grecia, haciéndolo remontar hasta Arquíloco ${ }^{22}$, si bien otros autores, como Kenner, han señalado precedentes del mismo en las civilizaciones sumeria y egipcia ${ }^{23}$. Para la literatura medieval el tema adquirió carta de naturaleza a través de los adynata de Virgilio, imitados por los poetas carolingios, pero se desarrolló sobre todo a partir del siglo XII en relación con el dinamismo cultural de esa centuria ${ }^{24}$. Pronto se extendió a la cultura figurativa, de tal suerte que a lo largo de la Baja Edad Media motivos del tópico del mundo al revés se prodigaron en la escultura monumental o en las sillerías de coro, amén de en los márgenes de los manuscritos que aquí son objeto de estudio. Al llegar el siglo xvi el tema encontró su vía de desarrollo en el grabado y, especialmente en Centroeuropa, en la pintura mural. Dando muestras de su vitalidad y de su capacidad de transformación, el tópico del mundo al revés cobró nuevo y re-

18 Estas apreciaciones no debieran extrañar lo más mínimo teniendo en cuenta que, según señala Domínguez Rodríguez respecto de los libros de horas del siglo xv, incluso las miniaturas de estos manuscritos, los manuscritos por excelencia, no constituyen nunca una ilustración del texto, sino que son convencionales y derivan de la tradición (Domínguez Rodríguez, Ana: Iconografía de los libros de horas del siglo xV de la Biblioteca Nacional, Editorial de la Universidad Complutense de Madrid, Madrid, 1993, tomo I, pp. 8-12).

19 Así lo definen tanto Caro Baroja, "mundo en el que el orden de las cosas está invertido" (Caro Baroja, Julio: El carnaval, Taurus Ediciones, Madrid, 1965, p. 47) como Pinon, "true reversal of normality», (Pinon, Roger: «From Illumination to Folksong; the Armed Snail, a Motif of Topsy-Turvy Land", en VV.AA.: Folklore Studies in the Twentieth Century (Proceedings of the Centenary Conference of the Folklore Society, 1978), D. S. Brewer y Rowman and Littlefield, Woodbridge-Totowa, 1980, p. 87).

20 Grant, Helen F.: "El mundo al revés", en VV.AA.: Hispanic Studies in Honour of Joseph Manson, The Dolphin Book Co., Oxford, 1972, pp. 122-123; Grant, Helen F.: "The World...», pp. 106-107 y 110.

21 Cocchiara, Giuseppe: Il mondo alla rovescia, Universale scientifica Boringhieri, Turín, 1981, pp. $206-207$.

22 Curtius, Ernst Robert: Literatura europea y Edad Media latina, Fondo de Cultura Económica, México-Madrid-Buenos Aires, 1976, tomo I, p. 144.

23 Grant, Helen F.: "El mundo...", p. 121. La referencia de la obra de Kenner, que no he podido consultar, es KENNER, Hedwig: Das Phänomen der verkehrten Welt in der griechisch-römischen Antike, Klagenfurt, 1970.

24 Curtius, Ernst Robert: Literatura europea..., tomo I, pp. 144-146. 
novado impulso en la cultura barroca española, donde con un sentido serio ligado al concepto de desengaño manifiesta desde el punto de vista conservador el sentimiento de inestabilidad propio de una sociedad en cambio ${ }^{25}$. El tópico del mundo al revés encontró su último refugio en los grabados populares, en las hojas sueltas impresas que en España reciben el nombre de aleluyas y que no parece que se dieran antes de comienzos del siglo xIx, frente a su desarrollo desde el siglo XVI en Italia, desde el siglo xviI en Alemania y en los Países Bajos y desde el siglo xviI en Francia y en Inglaterra. En estas hojas, elaboradas con destino a gentes de muy bajo nivel cultural, el tópico del mundo al revés se presenta desprovisto de cualquier carga moralizante o sentido serio y convertido en algo trivial ${ }^{26}$, no obstante lo cual pervive aún en nuestros días, aunque alejado de las manifestaciones de la alta cultura que en otros tiempos sirvieron de cauce a su desarrollo ${ }^{27}$.

Salvo escasas excepciones, existe un general acuerdo en que en el período aquí estudiado el tópico del mundo al revés es esencialmente inmovilista y en que sus inversiones, lejos de ser meros caprichos jocosos, tienen un carácter absolutamente indeseable ${ }^{28}$. Desde este punto de vista, el tópico del mundo al revés es relacionable con el espíritu de amarga melancolía apenas paliado por el sentimiento religioso que Huizinga percibe en el último período de la Edad Media ${ }^{29}$, pero para valorar su significado en este período nada resulta mejor que acudir a los testimonios contemporáneos. Así, el poeta inglés John Gower en su largo poema latino Vox clamantis, escrito a raíz de la revuelta campesina de 1381, se sirve de los motivos del tópico del mundo al revés para reflejar la inquietud que a él, terrateniente en Kent, le produjo tal acontecimiento. En sus versos los bueyes que, abandonando el arado, devastan los campos y asesinan a los hombres, los perros que ladran a los cazadores, los gatos que ya no cazan ratones, las aves de corral que se comportan como aves de rapiña o los caballos que son dominados por los burros no tienen nada de graciosos o de liberadores, sino que expresan la ira de Dios y la alteración del orden social ${ }^{30}$. Su contemporáneo el poeta francés Eustache Deschamps, por su parte, aunque no se refiera explícitamente a motivos del tópico del mundo al revés, alude en algunos de sus versos a la locura de los tiempos presentes en términos nada tranquilizadores: Temps de douleur et de temptacion, / Aages de plour, d'envie et de tourment, / Temps de langour et de dampnacion, / Aages meneur près du definement, / Temps plains d'orreur, qui tout fait faussement... ${ }^{31}$ En definitiva, por su subversión de los órdenes divino y humano establecidos, el tópico del mundo al revés sería visto por los poseedores de los lujosos manuscritos de los siglos xV y xVI que a continuación serán examinados como un elemento inquietante, como una llamada a la reflexión ${ }^{32}$.

25 Maravall, José Antonio: La cultura del Barroco, Editorial Ariel, Esplugues de Llobregat (Barcelona), 1975, pp. $313-314$.

26 Grant, Helen F.: «El mundo...», pp. 132-134; Grant, Helen F.: «The World...», p. 108.

27 Aunque no sea más que por citar un solo ejemplo de la pervivencia del tópico del mundo al revés en nuestros días, cabe recordar aquí que recientemente apareció en la página de humor de un ejemplar de la denominada prensa del corazón un tema tan característico del tópico del mundo al revés como el del gato que es perseguido por un ratón (Semana, núm. 2958, Madrid, 23 de octubre de 1996, p. 95), tema cuyas raíces en la cultura figurativa se remontan hasta el siglo XII, si bien en este caso, de acuerdo con los tiempos, el ratón es un ratón mecánico, lo cual exagera aún más la inversión.

28 Véanse, por ejemplo, las observaciones de Cocchiara y de Camille (Cocchiara, Giuseppe: Il mondo..., pp. 195-199; Camille, Michael: Image..., pp. 30-31 y 43-47).

29 Huizinga, Johan: El otoño de la Edad Media, Revista de Occidente, $7^{\text {a }}$ ed., Madrid, 1967, pp. 50-56.

30 Klingender, Francis: Animals in Art and Thought to the End of the Middle Ages, Routledge \& Kegan Paul, Londres, 1971, pp. 372-373.

31 Citado en Huizinga, Johan: El otoño..., p. 53.

32 De no ser por este carácter serio, difícilmente se explicaría el hecho de que estas imágenes fuesen ignoradas en el transcurso de los expurgos inquisitoriales de libros de horas que se produjeron después de Trento (sobre esta práctica, véase Docampo, Javier: “Un libro de horas...», loc. cit.). En el folio 194r del ms. Vit. 25-3 de la Biblioteca Nacional, un magnífico libro de horas francés del que serán examinadas varias imágenes, queda el testimonio de uno de estos expurgos: Por comisión de los señores inquisidores vi todo este libro y lo examiné. No ay en él cosa sospechosa ni mala y, así, por orden de sus merçedes, se buelve a mi señora doña Teresa y se da a su merced liçençia que lo tenga y use de él como fuere servida. Y en fe de ser esso verdad lo firmo... Así pues, no se consideraron cosa sospechosa ni mala las imágenes que aquí serán estudiadas ni otras aparentemente tan poco edificantes como la de un simio contorsionándose y haciendo ostentación de su ano (fols. 58r y 58v). 


\section{Cazadores cazados}

De entre la variedad de motivos posibles dentro del tópico del mundo al revés, tal vez el más representado sea el del cazador cazado, que admite una gran cantidad de combinaciones y variantes. Su popularidad se debió, en primer lugar, a la popularidad misma de la caza, pasatiempo aristocrático por excelencia ${ }^{33}$, que dotaba de una gran inmediatez a las imágenes con ella relacionadas (aunque éstas estén protagonizadas fundamentalmente por animales, sin apenas el concurso del hombre), pero también a su relación, apuntada por Varty, con otro motivo de gran popularidad, el de la rueda de la Fortuna ${ }^{34}$. Frente al carácter sintético y de fuerte efecto visual de la mayoría de las representaciones de este motivo en los manuscritos de los siglos XIII y xIV, se observa desde finales del siglo Xv una tendencia a potenciar su narratividad y a ofrecer un mayor desarrollo del mismo ${ }^{35}$, como se puede apreciar en algunos de los ejemplos de los manuscritos aquí examinados. En ellos, junto a temas tradicionales cuya trayectoria es bien conocida, he podido encontrar algún otro absolutamente novedoso, del que no da cuenta la abundante bibliografía al respecto.

La liebre fue la víctima a la que con mayor frecuencia se convirtió en depredadora de sus habituales cazadores, el perro y el hombre. Considerada en la Biblia animal impuro ${ }^{36}$, durante la Edad Media fue tenida por un símbolo de la lujuria debido a su natural facilidad para la procreación ${ }^{37}$, por lo que aquellas imágenes en las que aparece cazando al perro o al hombre pueden interpretarse como un triunfo del vicio de la lujuria ${ }^{38}$. En la literatura tanto el tema de la liebre cazadora como su versión menos cruenta en la que la liebre simplemente es capaz de entenderse amigablemente con el perro conocieron un temprano desarrollo. Éste aparece ya en Chrétien de Troyes ${ }^{39} \mathrm{y}$, pasando siglos y fronteras, se le encuentra también en los versos castellanos de los Disparates muy graciosos, donde en medio de su cúmulo de imposibles dice su autor: vi jugar al hanequín / un galgo con una liebre ${ }^{40}$. Su iconografía presenta numerosas variantes según el grado de desarrollo del tema y según la víctima elegida, la forma de apresarla, el castigo infligido a la misma, etc. ${ }^{41}$. En uno de los libros de horas de la Biblioteca Nacional, el ms. Vit. 24-10, obra flamenca de comienzos del último tercio del siglo XV a la que se ha puesto en rela-

33 Marle, Raimond van: Iconographie de l'art profane au Moyen Âge et à la Renaissance et la décoration des demeures, Hacker Art Books, Nueva York, 1971, tomo I, pp. 197-198 y 273-274.

34 Varty, Kenneth: Reynard the Fox. A Study of the Fox in Medieval English Art, Leicester University Press, Leicester, 1967, p. 82. Aunque de fecha muy avanzada con respecto al período que aquí estudio, merece la pena recordar la imagen de uno de los emblemas publicados por Sebastián de Covarrubias a comienzos del siglo xvir que bajo el título Io no sé quál va tras quál presenta a semejanza de la rueda de la Fortuna una doble rueda, recorrida por ratones y gatos la una y por liebres y galgos la otra, acompañada de unos versos alusivos al tópico del mundo al revés (Mateo Gómez, Isabel: Temas profanos en la escultura gótica española. Las sillerías de coro, Consejo Superior de Investigaciones Científicas, Madrid, 1979, p. 291).

35 Esta tendencia a ofrecer un desarrollo narrativo del motivo del cazador cazado es patente en las descripciones de Cocchiara de diversos grabados y pinturas murales del siglo xvi sobre el tema de la liebre cazadora donde se va relatando el apresamiento del cazador, su juicio, su ejecución... (Cocchiara, Giuseppe: Il mondo..., pp. 203-206). Frente a esto, las imágenes de los siglos xIII y xIV ofrecidas por Randall son mucho más simples y vigorosas (Randall, Lilian M. C.: Images..., figs. 100-101, 217, 224, 356-358 y 365 ).

36 Lev. 11, 6. Precisamente, por su bíblica condición de animal impuro la liebre fue utilizada a veces con una finalidad antisemita (véase, por ejemplo, la composición número 18 del Cancionero de obras de burlas..., p. 105). Sin embargo, no he percibido ninguna intencionalidad de este tipo en la miniatura, aunque conviene tenerla presente.

37 Klingender, Francis: Animals..., p. 471; Mateo Gómez, Isabel: Temas profanos..., pp. 86-87.

38 Mateo Gómez, Isabel: "El conejo cazador del "Jardín de las Delicias” del Bosco y una miniatura del siglo XIV", A.E.A., tomo XLV, Madrid, 1972, p. 167.

39 Curtius, Ernst Robert: Literatura europea..., tomo I, p. 146.

40 Cancionero de obras de burlas..., p. 272.

41 Randall, Lilian M. C.: Images..., figs. 217, 224, 228 300, 302, 354, 356-358, 365-366 y 569; Mateo Gómez, Isabel: Temas profanos..., pp. 292 y 436. 
ción con Lieven van Lathem con la participación de Nicolaas Spierinc ${ }^{42}$, aparece una curiosa versión de este tema en el margen de su folio 57r, presidido por una miniatura de la Anunciación que marca el comienzo de las horas de la Virgen. En ella un perro huye ante el acoso a que es sometido por parte de tres liebres, sujetas dos de ellas por una traílla gobernada por un hombre mientras la tercera se abalanza sobre el perro (Fig. 1). Lo excepcional de esta imagen es la presencia del hombre, que atenúa un tanto el efecto de inversión de la liebre cazadora al situarse por encima de ella, restándole protagonismo, mediante la sujeción de la traílla, cuando tradicionalmente había sido él mismo una de las víctimas de la liebre cazadora, que en el salterio de Gui de Dampierre, obra francesa de finales del siglo xiII, se permite incluso cazar a un hombre mediante un perro al que azuza haciendo sonar un cuerno ${ }^{43}$ en lo que constituye la más sencilla y acabada versión invertida del tema de la caza de la liebre. En el libro de horas ahora examinado, por contra, la liebre queda en una extraña posición intermedia. En esta escena se advierte ya esa tendencia a ofrecer un desarrollo narrativo del motivo de cazador cazado que se ha señalado como propia del arte de finales del siglo xv y del siglo xvI, según se aprecia en la ambientación de la escena en un terreno montuoso de vegetación baja o en el carácter de secuencia de la misma. Esta misma tendencia se puede apreciar en el margen del folio $65 \mathrm{r}$ de uno de los libro de horas de la Bibliothèque Nationale de France de París, el ms. lat. 1393, obra francesa de finales del siglo XV o de comienzos del siglo XVI ${ }^{44}$. En él, en un escenario puntualmente descrito, la liebre, protagonista absoluta, aparece consumando su venganza: ha atrapado al perro y lo ha ensartado en un palo y ahora lo está asando (Fig. 2). La figura del cazador situada en medio del bosque en segundo término, ajena a cuanto está sucediendo en primer término y llamando en vano a su perro con el cuerno, refuerza la dimensión narrativa de la escena sugerida ya por su ambientación. Esta versión del tema de la liebre cazadora resulta igualmente excepcional, aunque para el grupo principal de la misma, el de la liebre asando al perro, existe un claro precedente que será examinado un poco más adelante.

Al tema de la liebre cazadora no le va a la zaga en cuanto a recurrencia el del ratón que persigue, atrapa, custodia o ajusticia al gato. La enemistad entre estos dos animales, considerados ambos de naturaleza inmunda, era proverbial, pero, puesto que el gato era empleado para cazar los ratones, caen dentro del tópico del mundo al revés aquellas escenas en que ocurre justamente lo contrario ${ }^{45}$. Así se recoge en los Disparates muy graciosos: vi que estaban treinta gatos / roídos de tres ratones ${ }^{46}$. El tema es uno de los que aparecen desde época más temprana y su popularidad llega hasta nuestros días. Siempre se cita como el ejemplo más antiguo del mismo un capitel del claustro de la catedral de Tarragona de finales del siglo xII o de principios del siglo XIII en el que aparece una procesión de ratones llevando el cadáver del gato ${ }^{47}$. Sin embargo, no es ésta una escena de mundo al revés propiamente dicho, ya que en ella, tal y como se detalla, el gato sólo se ha fingido muerto para hacer presa en los ratones más fácilmente, emulando así una de las tretas más características del zorro. Dentro de este tema, la escena que con mayor frecuencia se representa es la del gato ahorcado por los ratones ${ }^{48}$. En el margen inferior del folio $27 \mathrm{v}$

\footnotetext{
42 Domínguez Rodríguez, Ana: Libros de horas..., p. 109; Dogaer, Georges: Flemish Miniature Painting in the 15th and 16th Centuries, B. M. Israël B. V., Amsterdam, 1987, pp. 133 y 137.

43 Randall, Lilian M. C.: Images..., fig. 357.

44 Leroquais, abbé V.: Les livres d'heures manuscrits de la Bibliothèque Nationale, París, 1927, tomo I, núm. 106, pp. 219-222.

45 Mateo Gómez, Isabel: Temas profanos..., pp. 78 y 292.

46 Cancionero de obras de burlas..., p. 270.

47 Cocchiara, Giuseppe: Il mondo..., pp. 190-191.

48 Randall, Lilian M. C.: Images..., fig. 101; Mateo Gómez, Isabel: Temas profanos..., p. 292; Varty, Kenneth: Reynard..., p. 83. Para otras variantes del tema del ratón que se enfrenta al gato, véase Randall, Lilian M. C.: Images..., figs. 98100 .
} 
del libro de horas de la Bibliothèque Nationale de France de París anteriormente aludido aparece pintada con la tendencia a la narratividad propia de este manuscrito y del período en que fue iluminado una escena que tal vez represente un momento previo al del ahorcamiento del gato. En ella dos ratones conducen a un gato maniatado en un pequeño barco (Fig. 3). Cabe poner en relación esta escena con algunos de los lugares comunes propios de los contes d'animaux medievales, donde es frecuente el episodio del juicio. Así, por ejemplo, en la branch XVII del Roman de Renard, datada por la crítica a comienzos del siglo XIII, el protagonista, el zorro Renard, se encuentra con la liebre Covard que ha cazado a un hombre y lo lleva preso a la corte de Noble para que sea juzgado ${ }^{49}$. Sin embargo, la escena aquí estudiada, en la que el barco resulta un elemento excepcional para el que no encuentro ni paralelo ni explicación, no pertenece a secuencia alguna en la que se desarrolle de forma completa un ciclo sobre la prisión, juicio y ejecución del gato, sino que sintetiza ella sola uno de los temas más comunes del motivo del cazador cazado ${ }^{50}$.

De mayores resonancias literarias es un tema extraño para el que no he encontrado precedentes, aunque la imagen que aquí presento sea el precedente más claro de la de la liebre asando al perro anteriormente examinada. Se trata del tema del gallo asando al zorro (Fig. 4) que aparece en la parte superior del margen derecho del folio 59r de un libro de horas de la British Library, el ms. Add. 29433, obra debida, salvo siete miniaturas, al maestro de las Iniciales de Bruselas y fechada en torno a 1406-1407. Esta imagen ya fue dada a conocer por Meiss, el cual, de acuerdo con su posición respecto al carácter significativo de la figuración marginal, la interpreta en relación con la miniatura del Nacimiento de Cristo que aparece tres folios más atrás con una doncella calentando las ropas del Niño y otra preparando un pollo, lo que, en su opinión, dota de un no aclarado carácter especialmente sugerente a esta imagen ${ }^{51}$. La imagen del zorro llevándose en sus fauces algún ave de corral, generalmente un pato o ganso, es bastante común en la iconografía medieval, probablemente porque no fue infrecuente en la vida campesina del momento, pero, caracterizado el zorro por el bestiario medieval como un animal astuto que se hace el muerto para que se le acerquen las aves y atraparlas entonces de improviso (traza también común en la iconografía medieval que, lejos de ser un producto de la imaginación de aquella época, ha sido comprobada científicamente), fue equiparado al demonio y su representación con un pato o ganso, animales simplones, en las fauces fue utilizada como una invitación a estar vigilantes frente a las argucias del Maligno ${ }^{52}$. Estas escenas contaron con su correspondiente correlato invertido en la escena del zorro ahorcado por los gansos ${ }^{53}$, pero el protagonismo del gallo en la imagen que aquí es objeto de análisis conduce al terreno de la literatura en la búsqueda de una interpretación. En efecto, en torno al zorro existió a lo largo de la Edad Media todo un ciclo literario de raíces antiguas que hacía de él, auténtico héroe villano, el protagonista y cuyo texto fundamental fue el anteriormente citado Roman de Renard, compuesto hacia 1175 por Pierre de Saint-Cloud y sucesivamente continuado e imitado ${ }^{54}$. En la literatura en torno a Renard el gallo

49 Varty, Kenneth: Reynard..., pp. 83-84.

50 Menos cruenta y más ambigua resulta la escena que aparece en uno de los más espléndidos libros de horas de la Biblioteca Nacional, el ms. Vit. 25-3, manuscrito francés de mediados del siglo xv adscribible a la escuela de Tours al que se aludió anteriormente en la nota 32. Tanto en el recto como en el vuelto del margen inferior de su folio 40 aparece un gigantesco animal sentado sobre un bloque y cubierto por una especie de capa blanca en actitud preeminente con respecto a una minúscula criatura que se encuentra a su lado. La identificación de ambos animales con ratón y con gato, respectivamente, es más que problemática (sobre todo por el carácter peludo de la cola del presunto ratón), pero, en el caso de que realmente lo fueran, la inversión se habría resuelto aquí no mediante la agresividad, sino mediante el juego de tamaños y de relaciones.

51 Meiss, Millard: French Painting... The Late Fourteenth..., p. 237, fig. 762.

52 Varty, Kenneth: Reynard..., pp. 26-28.

53 Varty, Kenneth: Reynard..., pp. 81-82.

54 Varty, Kenneth: Reynard..., p. 21. 

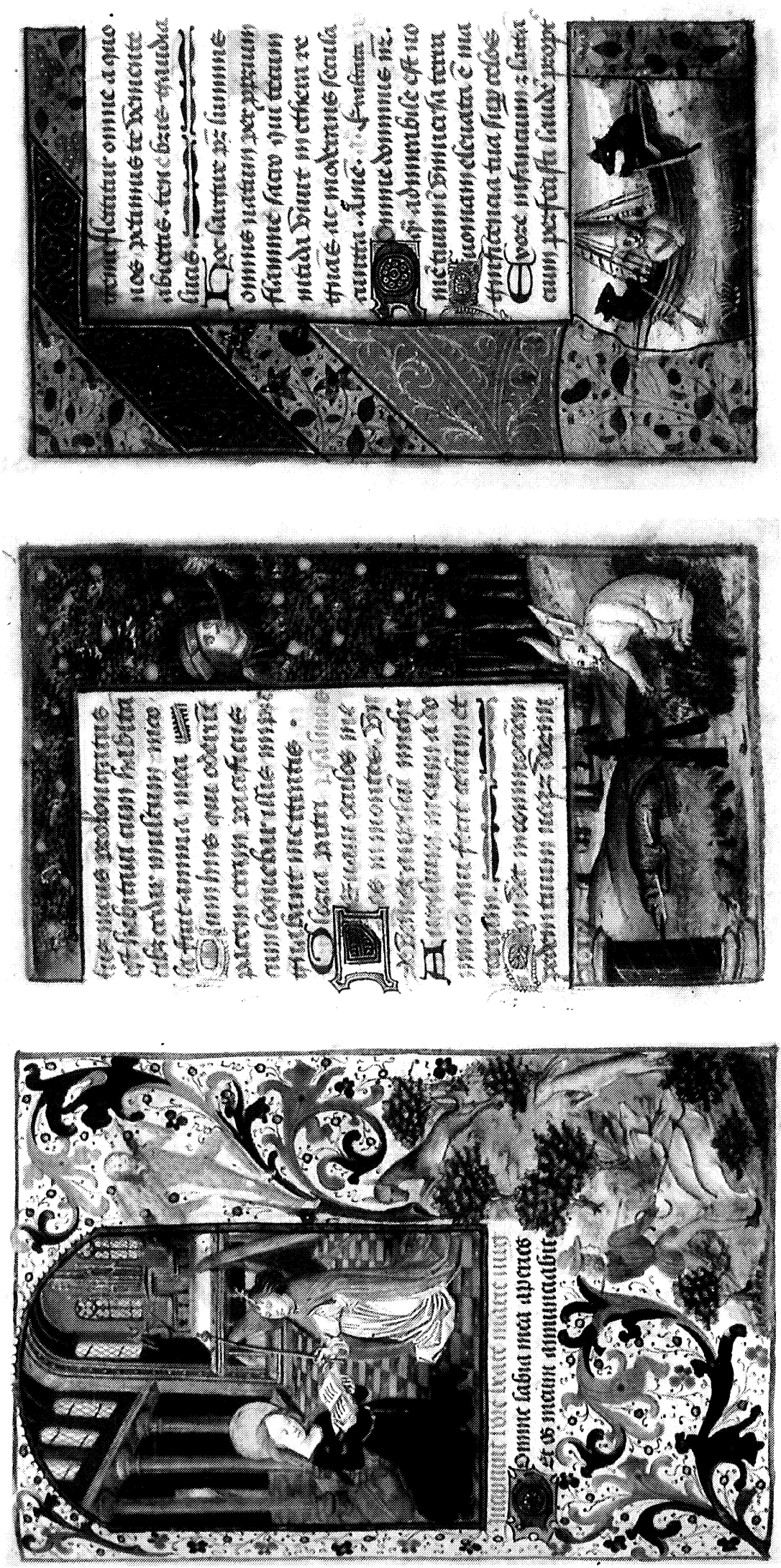

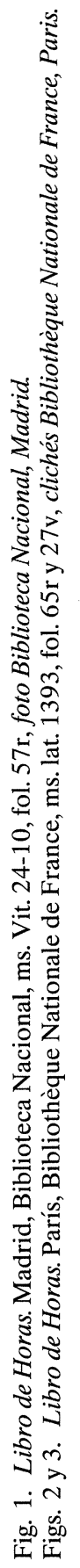


Chantecler, caracterizado por su vanidad y por su presunción, es uno de sus más antiguos y enconados enemigos y su historia una de la que más textos originó. En una ocasión Renard consiguió atrapar a Chantecler recordándole lo bien que cantaba su padre, que lo hacía con los ojos cerrados. Aunque en un primer momento Chantecler desconfió, el presumido gallo terminó por emular a su padre según los consejos del zorro y Renard aprovechó la ocasión para apresarle y huir con él, lo que fue ocasionalmente representado en las artes plásticas, aunque finalmente Chantecler logró librarse ${ }^{55}$. En otra ocasión, relatada en la branch XVII del Roman de Renard, estando en la corte de Noble, Renard fingió su muerte y durante su entierro se abalanzó sobre Chantecler y de nuevo huyó con él, hasta que se vio forzado a soltarle por el acoso al que le sometió un perro. Apresado Renard, Chantecler reclamó su derecho a luchar con él en combate singular. La pugna resultó durísima y finalmente Renard recurrió otra vez al truco de hacerse el muerto para salvarse y huir ${ }^{56}$. Todas estas historias debieron de ser bien conocidas por el maestro de las Iniciales de Bruselas, cuya cultura estima Meiss, y están implícitas en su curiosa imagen del gallo asando al zorro. Sin embargo, ésta no responde a ningún episodio concreto de la literatura renardiana. Su autor más bien establece un diálogo con ella desde la cultura figurativa aportando a la misma una conclusión: el zorro, ensartado en un palo y sintiendo ya las caricias de las llamas, no podrá fingir ya más su muerte. No obstante, la victoria del gallo, presa habitual del zorro, no deja de ser un aspecto más del tópico del mundo al revés.

Las profundas implicaciones literarias de este tema o la sólida tradición iconográfica en la que se insertan los otros dos analizados con anterioridad se desvanecen a la hora de afrontar el estudio de un último y excepcional tema en el que de nuevo se produce una inversión de los papeles de cazador y de cazado. En el margen inferior del folio $77 \mathrm{v}$ de otro libro de horas de la Biblioteca Nacional, el ms. Res. 187, obra francesa de entrado el siglo xvi muy ecléctica en la concepción de sus márgenes ${ }^{57}$, aparece la insólita imagen de una gran libélula abalanzándose sobre un pájaro y atrapándolo (Fig. 5). Personalmente, no conozco, por el momento, nada relacionable ni en la miniatura ni en la literatura, pero su carácter de inversión, su relación con el tópico del mundo al revés, exagerada por la diferente escala con que han sido representados ambos animales, está asegurada por la existencia de imágenes de pájaros cazando insectos. En este mismo manuscrito un pájaro cae sobre una mosca en el margen del folio 122r , tema bastante frecuente en los márgenes de las Horas de Carlos VIII (Madrid, Biblioteca Nacional, ms. Vit. 24-1), y en los márgenes de un libro de horas francés de finales del siglo xV de la Real Biblioteca de Palacio, el ms. II-2101, aparecen pájaros atrapando insectos de distinto tipo en varias de sus páginas. Todas estas representaciones deben ponerse en relación con la evolución de la decoración marginal a finales del siglo xv. El exitoso modelo impuesto a partir de los años ochenta de esa centuria por el maestro de María de Borgoña desplazó a los motivos tradicionales de la figuración marginal y concentró la atención de artistas y comitentes sobre las pequeñas realidades de la naturaleza ${ }^{58}$. El tema del pájaro cazado por el insecto sólo puede explicarse entonces como el fruto de una heterogénea conjunción de los nuevos modelos y de la vieja tradición.

\footnotetext{
55 Varty, Kenneth: Reynard..., pp. 31-33.

56 Varty, Kenneth: Reynard..., pp. 85-86.

57 Domínguez Rodríguez, Ana: Libros de horas..., p. 27.

58 Sobre la representación de insectos y de otras pequeñas criaturas con anterioridad, véase Klingender, Francis: Animals..., pp. 419-420. Una gran libélula aparece en el Salterio de Luttrell, de en torno a 1340 (Klingender, Francis: Animals..., fig. 353).
} 


\section{Combates desiguales}

Estrechamente relacionado con el motivo del cazador cazado está, dentro del tópico del mundo al revés, el del combate desigual, aquel en el que se enfrentan dos contendientes de capacidades muy poco equilibradas y en el que, sin embargo, la fortuna parece acompañar al menos dotado. El presentar criaturas diversas afrontadas con un aire más o menos beligerante fue un recurso muy utilizado en la figuración marginal, a menudo con un carácter estrictamente decorativo ${ }^{59}$. Por eso aquí sólo serán tenidas en cuenta aquellas imágenes en las que, de acuerdo a las reglas de inversión propias del tópico del mundo al revés, se representa a seres esencialmente reales y reconocibles.

En los folios 95r y 120r de uno de los libros de horas de la Real Biblioteca de Palacio, el ms. II-2099, obra debida al maestro de las Iniciales de Bruselas y fechada en torno a 1400, este artista italiano que tanto contribuyó al desarrollo de la figuración marginal a comienzos del siglo XV ofrece dos versiones de un mismo tema en el que un hombre, armado con una enorme espada y en uno de los casos protegido por una rodela, combate denodadamente a una extraña criatura con rasgos de pájaro de la que sólo son visibles la cabeza y el largo pico, contrincante temible de la espada (Fig. 6). En las Decretales Smithfield, obra inglesa del segundo cuarto del siglo xIv, aparecen grandes pájaros de largo pico atacando a hombres ${ }^{60} \mathrm{y}$ es posible que todas estas imágenes tengan algo que ver con la relación entre el pájaro y la sodomía apuntada por Camille a propósito de una fábula y patente en un pontifical del siglo xv conservado en la catedral de Toledo ${ }^{61}$.

Similar es el tono del tema pintado por los Limbourg en el ángulo superior izquierdo del margen del folio $38 \mathrm{v}$ de las Très Riches Heures del duque de Berry, donde un ser híbrido, mitad hombre y mitad bestia, semicubierto por un manto azul, color característico del engañado o del loco ${ }^{62}$, combate con furia a unas inofensivas mariposas armado con una espada y protegido por una rodela. Juegos con mariposas se habían dado ya en la figuración marginal del siglo xIV ${ }^{63}$, pero la actitud beligerante de las mariposas de los Limbourg resulta insólita, si bien Pinon recoge versos de algunas composiciones en las que las mariposas se arman o participan en combates ${ }^{64} \mathrm{y}$, aunque cambiando de insecto, su mismo espíritu late en los versos de los Disparates muy graciosos que dicen: vi una lanza y un pavés / huir de un escarabajo ${ }^{65}$, todo lo cual sitúa en un contexto bien definido la poco frecuente imagen ofrecida por los Limbourg.

Pero sin duda el combate desigual por excelencia de la figuración marginal es el que enfrenta a un caracol con un hombre armado o con un animal más poderoso que él. El caracol es uno de los animales sobre los que se ha acumulado un mayor número de significados a lo largo de la historia. Ha sido tenido por símbolo del oportunismo, de la desconfianza, de la resurrección, de la prudencia, de la discreción... ${ }^{66}$, pero el tema del combate entre el guerrero y el caracol encierra, de acuerdo con las normas de inversión propias del tópico del mundo al revés, una clara alusión a la cobardía o al falso coraje humanos. Este tema ha sido objeto de estudios pormenorizados

\footnotetext{
59 Véase, por ejemplo, el partido que se saca a este recurso en los mss. 12 y 13 de la Biblioteca Nacional, obra francesa de comienzos del siglo xvi que contiene escritos de San Ambrosio.

60 Randall, Lilian M. C.: Images..., fig. 331.

61 Camille, Michael: Image..., p. 54. En uno de los márgenes del aludido pontifical un ave zancuda introduce su largo pico en el ano de un simio (Archivo Fotográfico del Departamento de Historia del Arte "Diego Velázquez" del C.S.I.C., núm. 50224).

62 Huizinga, Johan: El otoño..., p. 432.

63 Klingender, Francis: Animals..., pp. 418-419.

64 Pinon, Roger: "From Illumination...», p. 83.

65 Cancionero de obras de burlas..., p. 271.

66 Randall, Lilian M. C.: "The Snail...», pp. 360-362; Mateo Gómez, Isabel: Temas profanos..., pp. 52-54.
} 

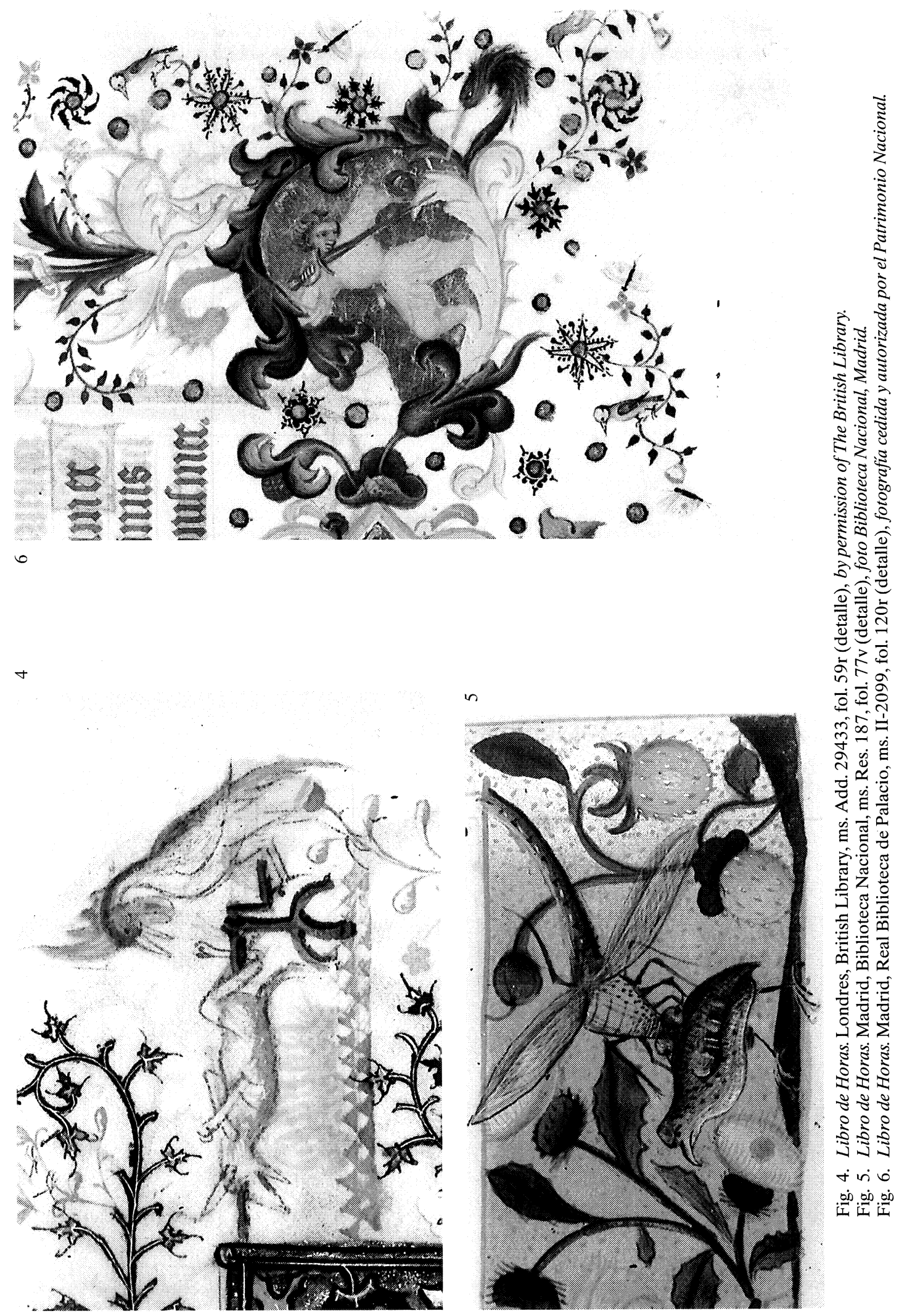
por parte de Randall, de Pinon y de Pedrosa ${ }^{67}$. Según estos autores, al tópico de la cobardía de los lombardos, fundado en diversos textos sobre la actuación de las tropas lombardas frente al ejército de Carlomagno, se unió en un momento indeterminado, con anterioridad, en todo caso, al siglo XII, el motivo del caracol que se encara con un hombre armado. El tema resultante conoció un éxito inusitado. A finales del siglo XII se plasmó en un texto de resonancias ovidianas, De Lombardo et lumaca, y las referencias al mismo no escasean entre los siglos XII y XIV, momento en el que, desde los últimos años del siglo xiII, aparece con frecuencia en los márgenes de los manuscritos. Randall atribuye esta popularidad del tema en la figuración marginal no sólo a su popularidad literaria, sino también a la posición de los lombardos como prestamistas en los países donde se produjeron los manuscritos en los que aparece el tema, lo que haría de ellos personajes poco susceptibles de simpatías y cobardes a priori por la naturaleza de su profesión ${ }^{68}$. Según esta autora, en la iconografía el tema fue decayendo a lo largo del siglo xiv y sólo fue recuperado a finales del siglo xv en relación con sucesos contemporáneos, pero tanto Pinon como Pedrosa hacen hincapié en la pervivencia del tema a través de sus transformaciones y en su vigencia en el folklore. En una de las composiciones recogidas por Hernando del Castillo en su Cancionero general dentro de la sección de obras de burlas provocantes a risa el poeta interpela a un tal García de Huete sobre cierta herida de su rostro y éste, tras dar varias explicaciones, dice: mas díxome un viejo anciano / que es rastro de caracol; / yo le respondo al villano / que le llame re mi fa sol ${ }^{69}$. El enfado de García de Huete ante el descubrimiento de su falso coraje prueba la difusión y la vigencia del tema a finales del siglo xv.

Desde luego, el tema aparece en la figuración marginal del siglo xv en mayor medida que la apuntada por Randall. Pinon aduce el ejemplo de un libro de horas flamenco conservado en la Bibliothèque de la Chambre des Députés de París en el que un caracol se enfrenta a una especie de hombre salvaje ${ }^{70}$ y a éste se pueden añadir otros más, como el debido a los hermanos Limbourg que aparece de nuevo en el margen izquierdo del folio $38 \mathrm{v}$ de las Très Riches Heures del duque de Berry, en el que la desigualdad entre ambos contendientes resulta enfatizada por el encastillamiento del guerrero que, fuertemente protegido por su armadura, hostiga al caracol con su lanza mientras encorvado se protege detrás de su escudo. La imagen ofrecida por los Limbourg se ajusta a la variante más tradicional del tema, enriquecida tan sólo por la incorporación del castillo como elemento enfático, que, sin embargo, cuenta con precedentes en algunas imágenes de ratones atacando a gatos o de liebres atacando a hombres ${ }^{71}$. Variantes más avanzadas aparecen en algunos manuscritos conservados en bibliotecas españolas. En el margen inferior del folio 13r de un devocionario de la Real Biblioteca del Monasterio de San Lorenzo de El Escorial, el ms. D.IV.13, obra flamenca de en torno a $1490{ }^{72}$, aparece un simio o salvaje armado con una espada y protegido por una rodela haciendo frente a un caracol (Fig. 7). La sustitución del guerrero por el simio no debe resultar en absoluto extraña ${ }^{73}$ habida cuenta de la frecuencia con que este animal protagoniza todo tipo de escenas en los márgenes, a menudo remedando

\footnotetext{
67 Randall, Lilian M. C.: "The Snail...»; Pinon, Roger: «From Illumination...»; Pedrosa, José Manuel: Las dos sirenas y otros estudios de literatura tradicional, Siglo XXI de España Editores, Madrid, 1995, pp. 121-132.

68 Randall, Lilian M. C.: "The Snail...», pp. 366-367.

69 Cancionero de obras de burlas..., núm. 41, pp. 141-142.

70 Pinon, Roger: «From Illumination...», p. 99.

71 Randall, Lilian M. C.: Images..., figs. 99 y 354.

72 Domínguez Bordona, Jesús: Manuscritos..., tomo II, núm. 1316, p. 26. Este autor lo considera francés, pero creo que se trata claramente de una obra flamenca de un artista secundario, de dibujo un tanto torpe, que, aunque conoce ya los márgenes característicos de la escuela de Gante-Brujas, apenas se sirve de ellos, siguiendo fiel a la tradición. Aunque se le llama devocionario, presenta los elementos característicos de un libro de horas.

73 De hecho, tanto Randall como Pinon se refieren ya a ella (Randall, Lilian M. C.: "The Snail...", p. 359; Pinon, Roger: "From Illumination...", p. 80).
} 
comportamientos humanos, pues no en vano San Isidoro hacía derivar su nombre, simio, de similitudo, por su facilidad para la imitación. En el margen inferior del folio 72v del ms. Res. 187, un libro de horas de la Biblioteca Nacional comentado ya a propósito de la imagen de la gran libélula que se abalanza sobre un pájaro, aparece de nuevo un caracol, afrontado esta vez con una bestia de aspecto fiero no identificable con ningún animal concreto, aunque tampoco destacan en ella rasgos especialmente antinaturalistas (Fig. 8). Aquí la elección del contrincante del caracol se justifica por la ausencia de figuras humanas propia de los márgenes de este manuscrito debido a su avanzada cronología y a su deuda con la tradición representada por la escuela de Gante-Brujas y, en todo caso, cuenta con precedentes en los que el contrincante del caracol es un león o un dragón ${ }^{74}$.

\section{Mujeres dominantes}

Apenas es necesario un comentario sobre la situación de la mujer en la Edad Media. Considerada instrumento de perdición, idea que encontró a veces expresiones literarias verdaderamente terribles ${ }^{75}$, su sujeción al hombre era tenida por natural, especialmente en el seno del matrimonio, que, lejos de ser considerado una relación entre iguales, era entendido en los textos de inspiración aristotélica como un régimen bien ordenado donde al gobierno del marido había de corresponder la obediencia de la esposa ${ }^{76}$. Por ello es por lo que deben considerarse dentro del tópico del mundo al revés aquellas imágenes en las que la mujer ocupa una posición preeminente con respecto al hombre, imágenes, por ejemplo, en las que el hombre hila mientras la mujer detenta la autoridad doméstica, en las que el hombre recibe una zurra por parte de la mujer, en las que el hombre sirve de animal de tiro a la mujer o en las que, enlazando con el motivo analizado en el apartado anterior, un hombre y una mujer se enfrentan en desigual combate yendo ésta a menudo armada tan sólo con su huso y con su rueca, verdaderas arma mulieris ${ }^{77}$. En el margen inferior de un libro de horas de la Österreichische Nationalbibliothek de Viena, el ms. 1857, compleja obra flamenca debida a varios artistas cuya decoración marginal debió de correr a cargo, fundamentalmente, de Nicolaas Spierinc ${ }^{78}$, aparece un híbrido masculino protegido por una armadura y fuertemente armado acometiendo a una hembra de simio desnuda (sustitución esta de la mujer por la hembra de simio que no debe resultar en absoluto extraña a la luz de lo comentado en el apartado anterior) que se dispone a arrojarle su huso ${ }^{79}$. Todas estas imágenes,

\footnotetext{
74 Randall, Lilian M. C.: «The Snail...», p. 359; Pinon, Roger: «From Illumination...», pp. 80 y 87 . También en el margen inferior del folio 81r de las anteriormente citadas Horas de Carlos VIII aparece un caracol a lomos de una bestia que vuelve su cuello para afrontar fieramente su rostro con el diminuto del caracol, pero aquí la bestia es ya abiertamente una criatura fantástica.

75 En efecto, a finales del siglo XI el abad Geoffroy de Vendôme escribió: Este sexo ha envenenado a nuestro primer padre, que era también su marido y su padre, ha decapitado a San Juan Bautista y llevado a la muerte al valiente Sansón. En cierto modo, también, ha matado al Salvador, pues, si su falta no se lo hubiera exigido, nuestro Salvador no habrí tenido necesidad de morir. ;Ay de ese sexo, en el que no hay temor, ni bondad, ni amistad, y al que más hay que temer cuando se lo ama que cuando se lo odia (citado en VV.AA.: Historia de las mujeres en Occidente, Taurus Ediciones, Madrid, 1992, tomo 2 (La Edad Media), p. 34). Siglo y medio después apenas le fue a la zaga el anónimo redactor de la versión castellana del Sendebar. que dize el sabio "aunque se tornase la tierra papel, e la mar tinta e los peçes d'ella péndolas, que non podrían escrevir las maldades de las mujeres» (Sendebar, edición de María Jesús Lacarra, Ediciones Cátedra, Madrid, 1989, pp. 154155).

76 Yarza Luaces, Joaquín: Formas artísticas de lo imaginario, Editorial Anthropos, Barcelona, 1987, pp. 231-235; VV.AA.: Historia de las mujeres..., tomo 2, pp. 139-141 y 333-334.

77 Mateo Gómez, Isabel: Temas profanos..., pp. 293-294.

78 Dogaer, Georges: Flemish Miniature..., p. 137.

79 Dogaer, Georges: Flemish Miniature..., fig. 85. Precedentes de finales del siglo xiI del tema del combate entre el guerrero y la mujer en Randall, Lilian M. C.: Images..., figs. 708-709.
} 

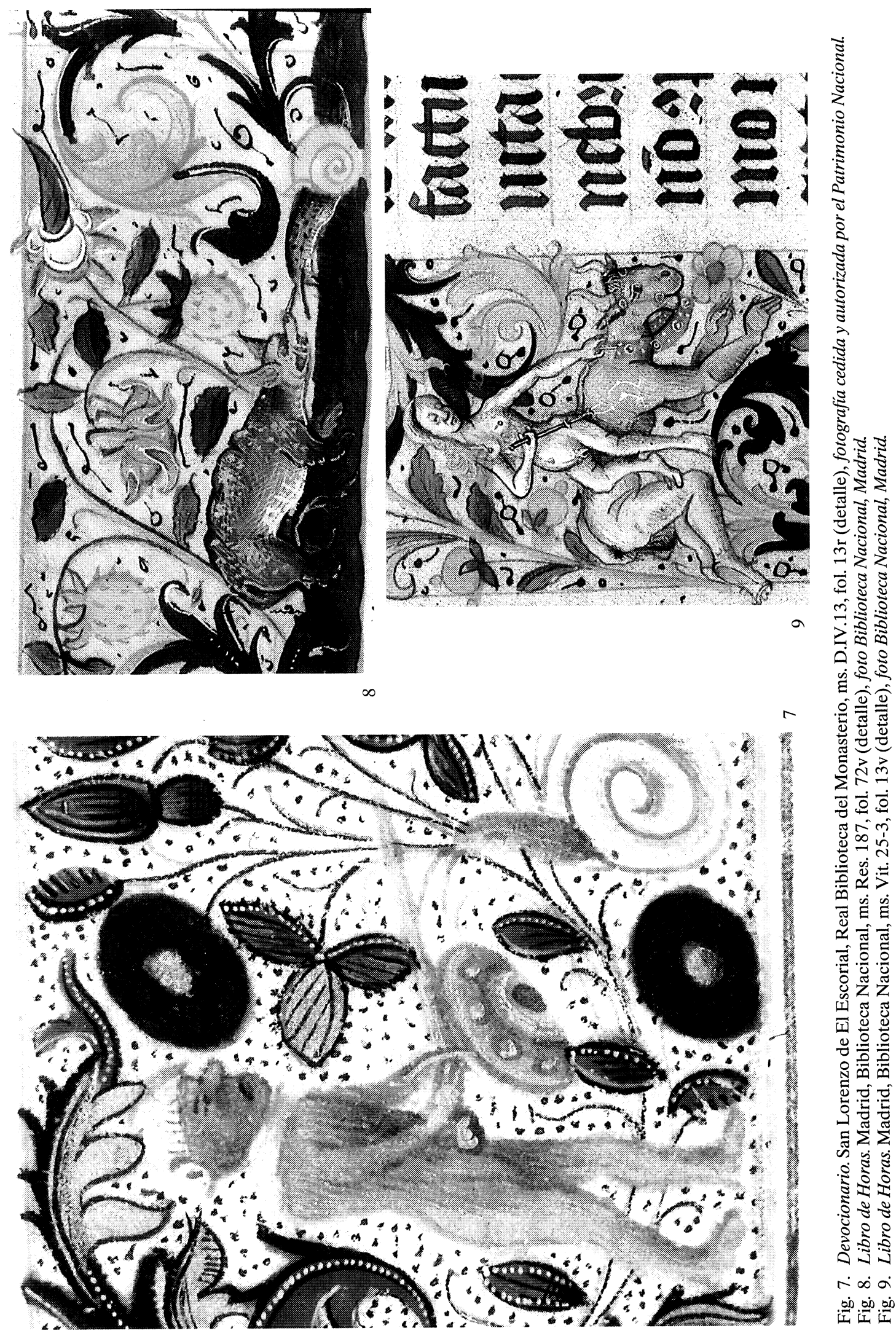
cuya pervivencia se manifiesta en los grabados populares e incluso se deja sentir en la actualidad, participan de la naturaleza inmovilista e inquietante del tópico del mundo al revés. Tanto Grant como Camille subrayan este carácter frente a quienes, como Verdier, abogan por un papel activo, con tintes liberadores, de la mujer en la figuración marginal 80.

En otro de los libros de horas de la Biblioteca Nacional, el ms. Vit. 25-3, obra francesa de mediados del siglo $\mathrm{xv}$ perteneciente a la escuela de Tours ${ }^{81}$, aparecen dos imágenes adscribibles al motivo de la mujer dominante. La más interesante de ellas, por su deuda con un tema de larga tradición que, a la vez, resulta transformado, aparece en el margen izquierdo del folio 13v. En ella una mujer desnuda cabalga sobre un híbrido masculino desnudo con cabeza de toro al que estimula mediante un azote y al que domina a través de unas lujosas riendas (Fig. 9). De inmediato esta imagen evoca el conocido tema de Aristóteles y Filis que con características similares aparece en los márgenes de los manuscritos y en otro tipo de obras de arte desde finales del siglo xiII ${ }^{82}$. La historia del engaño al que fue sometido el viejo y grave filósofo por parte de la joven y hermosa Filis, Campaspa en algunas versiones, fue muy popular en la Baja Edad Media. Se contaba en ella cómo, habiendo advertido Aristóteles a su discípulo Alejandro sobre la necesidad de no desatender los asuntos de estado por el amor que sentía hacia la bella Filis, ésta decidió vengarse del filósofo presentándose ante él para excitar su pasión, logrado lo cual le exigió como prueba de su amor que se pusiese a cuatro patas y la llevase sobre sus espaldas, a lo que Aristóteles accedió de inmediato sin advertir que Alejandro estaba contemplando la escena, lo cual le permitió, a la postre, darle a su discípulo una lección tanto más elocuente sobre el funesto atractivo de la mujer. La historia de Aristóteles y Filis se relaciona así temática e iconográficamente con la de otros grandes hombres llevados a la ruina por la acción de la mujer, como los bíblicos Adán, Sansón, Salomón, San Juan Bautista... o el pagano Virgilio, de quien se contaba una historia muy similar a la de Aristóteles ${ }^{83}$. Esta historia, ajena por completo a las fuentes antiguas, deriva de un cuento oriental adaptado e introducido en el flujo de la cultura occidental con un claro propósito moralizante por Jacques de Vitry, eclesiástico francés que pasó varios años de su vida en Ultramar y que al hacer de Aristóteles el protagonista de su versión latina del cuento del visir ensillado y embridado pretendió no sólo advertir frente al peligro representado por la mujer, sino también desacreditar al filósofo a quien cada vez se prestaba mayor atención en los medios universitarios ${ }^{84}$. La popularidad de su historia, sin embargo, se debió a la versión que de la misma ofreció pocos años después el canónigo de la catedral de Rouen Henri d'Andeli en su Lai d'Aristote, pronto imitado en otras lenguas, si bien este relato nunca pasó ni a las biografías latinas de Aristóteles ni al ciclo de la leyenda de Alejandro.

Aun cuando es claro que la imagen que aquí es objeto de estudio remite al tema de Aristóteles y Filis, no son menos significativas las variantes que presenta, comenzando por la extraña sustitución de Aristóteles, representado siempre como un hombre maduro con un tocado que destaca su condición de sabio, por un híbrido masculino con cabeza de toro. En alguna ocasión anterior Aristóteles había sido representado como un ser híbrido ${ }^{85}$, pero aquí el elemento reem-

${ }^{80}$ Grant, Helen F.: «The World...», pp. 114 y 118; Verdier, Philippe: “Woman in the Marginalia of Gothic Manuscripts and Related Works", en VV.AA.: The Role of Woman in the Middle Ages (Papers of the 6th Annual Conference of the Center for Mediaeval and Early Renaissance Studies at the State University of N. Y., Binghampton, 1972), R. T. Morewedge, Binghampton, 1975, p. 161; Camille, Michael: Image..., p. 127.

81 Domínguez Rodríguez, Ana: Libros de horas..., p. 117.

82 Randall, Lilian M. C.: Images..., figs. 554-555 y 557.

83 Marle, Raimond van: Iconographie..., tomo II, pp. 479-496.

${ }^{84}$ Adhémar, Jean: Influences antiques dans l'art du Moyen Âge français, The Warburg Institute, Londres, 1939, p. 297.

85 Verdier menciona el caso del bas-de-page del folio 103r de las Horas de Jeanne d'Evreux (Nueva York, The Metropolitan Museum of Art, The Cloisters Collection, ms. Acc. 54 (1.2)), donde una Filis música cabalga sobre una figura compuesta a la que, sin embargo, de acuerdo con la tradición, se ha dotado de un rostro maduro y barbado (Verdier, Philippe: "Woman in the Marginalia...”, p. 127). 
plazado es el más significativo, la cabeza. Por otra parte, el énfasis puesto en esta imagen en la desnudez de los dos personajes y en resaltar sus órganos genitales tiene unas connotaciones lúbricas que van mucho más allá de lo habitual en este tema. Cabe la posibilidad de que, para amplificar la idea del poder destructor de la mujer y de los desastres a que puede conducirle al hombre la lujuria, el artista haya pretendido combinar en una única imagen el tradicional tema de Aristóteles y Filis con una representación invertida del tema del rapto de Europa en el que la joven, abandonando su papel de víctima, gobierna al toro en lugar de ser arrebatada por él. Por el momento no está documentada la existencia de imágenes invertidas del tema del rapto de Europa que pudieran permitir verificar esta hipótesis, pero, desde luego, Ovidio fue un autor bien conocido en la Baja Edad Media y sus Metamorfosis fueron empleadas con fines simbólicos. Mâle da cuenta de un manuscrito de Ovidio de comienzos del siglo XIV de la Bibliothèque de l'Arsenal de París, el ms. 5069, Le roman des fables d'Ovide le Grand, en el que aparecen intercaladas escenas paganas y escenas cristianas y en el que el texto ofrece una aclaración sobre tal mezcla utilizando los temas ovidianos como prefiguraciones de las verdades cristianas. En él el tema del rapto de Europa es interpretado en clave cristológica: Júpiter transformado en toro sería un trasunto de Cristo, el buey del sacrificio que acepta la carga de todos los pecados de la humanidad ${ }^{86}$. Es evidente que la imagen aquí analizada no tiene nada que ver con este significado casi tipológico, pero, por lo menos, permite atestiguar el uso del tema del rapto de Europa con otra finalidad que la meramente ilustrativa, lo que allana el camino a la aceptación de la hipótesis propuesta.

Mucho menos compleja desde el punto de vista de su interpretación resulta la imagen que aparece en el folio 48, tanto en el recto como en el vuelto, en sus márgenes laterales. En ella aparece un hombre desnudo portando una rueca mientras debajo de él una mujer, también desnuda, de tez mucho más fina, se pone su ropa interior (Fig. 10). Se trata del característico tema de la inversión de los roles de los sexos. En la cultura figurativa los instrumentos propios de la hilatura se habían convertido en los atributos femeninos por excelencia, con raíces tanto en la cultura clásica (en la historia, por ejemplo, de Heracles y Ónfale, en la que se cuenta cómo el héroe fue dominado por la brava reina de Lidia, que le puso en su séquito femenino y le dio su rueca, quedándose ella con su cachiporra y con su piel de león ${ }^{87}$ ) como en la cristiana, donde en la división del trabajo que sucede al pecado original Adán ara y Eva hila, aunque luego la realidad fuese mucho más compleja ${ }^{88}$. En cualquier caso, los teóricos medievales consideraban que el trabajo era una forma de custodia necesaria para la mujer por su naturaleza voluble y débil ${ }^{89}$, por lo que la rueca, el huso o la devanadera, como atributos femeninos, son también testimonios de la inferioridad de la mujer y de su posición de sumisión con respecto al varón. En la imagen que ahora analizo, frente a la desnudez del hombre que en contra del orden natural y divino porta una rueca, aparece una mujer no sólo desprovista de sus tradicionales atributos, sino también vistiéndose, lo que remite al tema de la vestidura como símbolo de la autoridad doméstica que en unas ocasiones la mujer disputa ventajosamente al hombre y en otras simplemente la ostenta mientras el sumiso esposo se ocupa de la hilatura ${ }^{90}$.

\footnotetext{
86 Mâle, Émile: El gótico. La iconografía de la Edad Media y sus fuentes, Ediciones Encuentro, Madrid, 1986, p. 336.

87 Grant, Helen F.: «The World...», p. 115. Otros relatos sobre la inversión de los roles de los sexos afectan a Dioniso, a Aquiles...

88 Yarza Luaces, Joaquín: Formas..., pp. 239-240; VV.AA.: Historia de las mujeres..., tomo 2, pp. 356-357 y 365-366.

89 VV.AA.: Historia de las mujeres..., tomo 2, pp. 121-123.

90 Maeterlinck, L.: Le genre satirique..., pp. 105-108; Randall, Lilian M. C.: Images..., fig. 576; Marle, Raimond van: Iconographie..., tomo II, pp. 473-474.
} 


\section{Animales que actúan en contra de su naturaleza}

Todavía cabe distinguir un último grupo de temas adscribibles al tópico del mundo al revés, aquel en el que los protagonistas son animales que actúan como seres humanos e incluso se les sobreponen. Tanto las fábulas antiguas como los contes d'animaux medievales familiarizaron a las gentes con animales que se relacionaban y se comportaban de manera análoga a la de los seres humanos y de la difusión de estos temas da cuenta su enorme éxito iconográfico, a menudo ligado a intereses didácticos o moralizantes. Sin embargo, creo que en este tipo de imágenes tan sólo cabe hablar de mundo al revés cuando entra en juego los seres humanos y se sitúan por debajo de los animales. En el relato bíblico de la creación había quedado establecido un orden jerárquico entre las criaturas de acuerdo con los designios divinos. En aquellas imágenes en las que el hombre se sitúa por debajo de los animales ese orden divino se trastoca y se entra, por lo tanto, en el terreno del tópico del mundo al revés ${ }^{91}$. Este tipo de imágenes fue uno de los que más fortuna conoció en los grabados populares, donde se da un gran número de variantes del mismo con un regusto por el absurdo ajeno a las implicaciones del tema a finales de la Edad Media.

En el margen izquierdo ya varias veces mencionado del folio $38 \mathrm{v}$ de las Très Riches Heures del duque de Berry, los hermanos Limbourg ofrecen todavía una última imagen adscribible al tópico del mundo al revés. En ella un hombre empuja una especie de carretilla en la que se encuentra cómodamente sentado un cerdo que va tocando la cornamusa. Se funden en esta imagen dos temas bien conocidos. Por una parte, el del animal que toca un instrumento musical y, por otra parte, el del hombre que sirve de bestia de tiro a un animal, en el que reside la auténtica inversión. El tema del animal que toca un instrumento musical es bastante habitual desde el siglo XII y en él la asociación del cerdo con la cornamusa es especialmente frecuente ${ }^{92}$. Mateo interpreta esta asociación como una referencia a la lujuria tanto a partir del simbolismo tradicional de este animal como a partir de una referencia literaria ${ }^{93}$. En cuanto al tema del hombre que sirve de bestia de tiro a un animal, uno de los que más persistieron en los grabados populares, cabe ponerlo en relación con un refrán neerlandés recordado por Lyna y bien conocido a finales de la Edad Media, Hij zit op de kruiwagen (él está sentado en la carretilla), que aludía a la pereza y que fue plasmado en la cultura figurativa en la representación de un campesino que empuja una carretilla sobre la que se encuentra un noble, un clérigo o, mejor aún, un caracol ${ }^{94}$. Suma de lujuria y de pereza, esta imagen ofrecida por los Limbourg es un claro ejemplo de cuanto de negativo e indeseable hay en el tópico del mundo al revés.

En el margen derecho del folio 50r de otro de los libros de horas de la Biblioteca Nacional, el ms. Vit. 24-2, obra debida a Willem Vrelant y fechada en torno a 1465-1470 ${ }^{95}$, muy rica en cuanto a su figuración marginal, aparece un animal que sostiene una redoma junto a un hombre representado de medio cuerpo emergiendo de un tallo (Fig. 11). El ademán apesadumbrado del hombre nos aclara que tal representación no es sino una escena médica en la que el animal, según las pautas de inversión propias del tópico del mundo al revés, se hace cargo de la salud del hombre. Una composición similar, aunque protagonizada por dos hombres, aparece en el ángulo inferior izquierdo del folio $245 \mathrm{v}$ del volumen cuarto, próximo al estilo de Vrelant, de un manuscrito de las Crónicas de Jean Froissart (París, Bibliothèque Nationale de France, ms. fr. 2646) ${ }^{96}$.

91 Grant, Helen F.: "The World...", p. 107.

92 Evans, E. P.: Animal Symbolism in Ecclesiastical Architecture, William Heinemann, Londres, 1896, pp. 232-233; Klingender, Francis: Animals..., p. 434; Cocchiara, Giuseppe: Il mondo..., p. 193.

93 Mateo Gómez, Isabel: Temas profanos..., p. 65.

94 Lyna, Frédéric: «La bordure...», p. 4.

95 Domínguez Rodríguez, Ana: Libros de horas..., p. 78.

96 Catálogo de la exposición La miniature flamande. Le mécénat de Philippe le Bon, Bruselas, 1959, p. 134, pl. 52. Dogaer pone este manuscrito en relación con Philippe de Mazerolles (Dogaer, Georges: Flemish Miniature..., p. 124). 

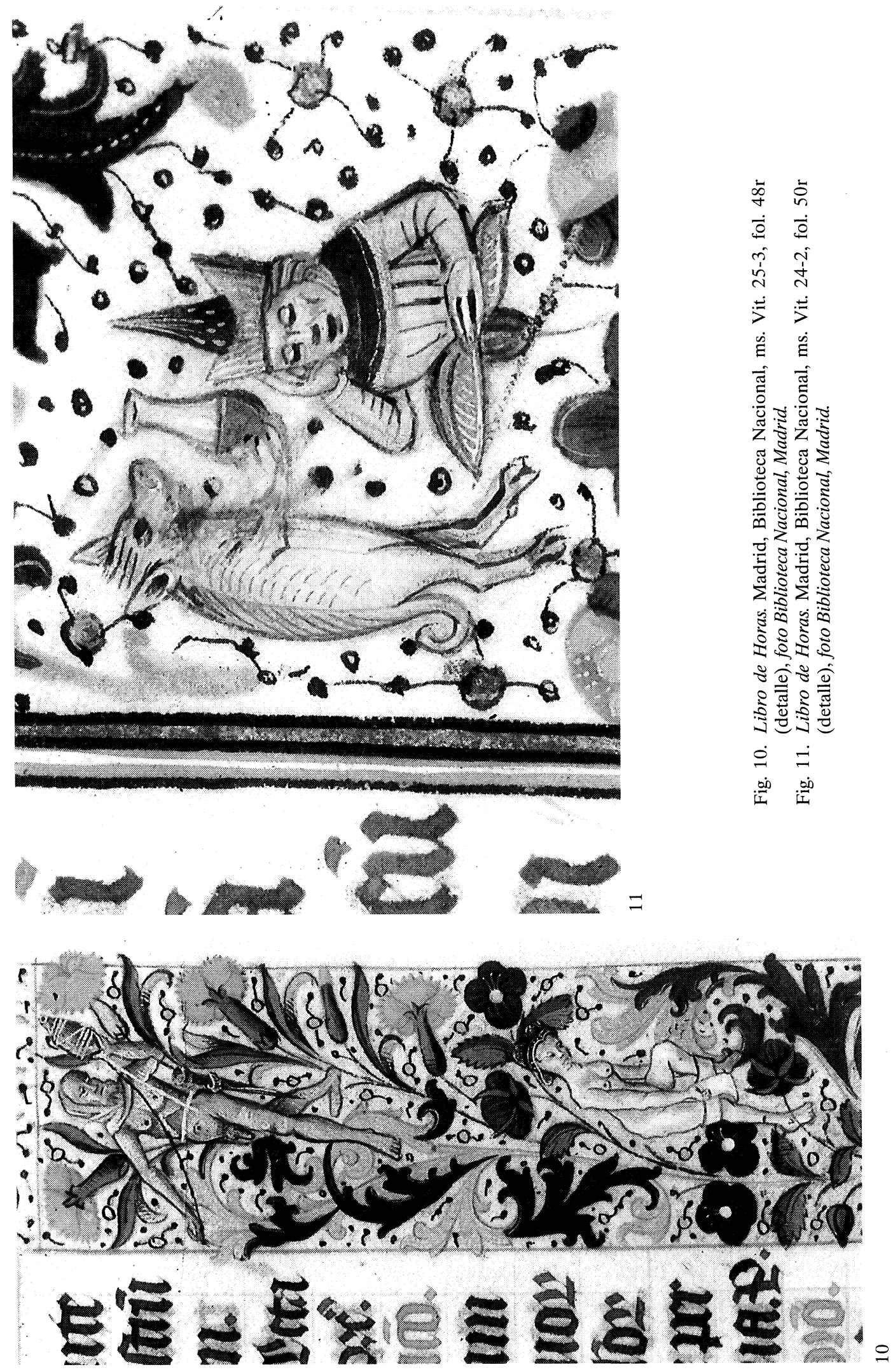
En ella el hombre que sostiene la redoma sostiene además un libro abierto en el que parece estar cifrado todo su saber, el cual libro ya no aparece en la versión invertida del tema. El actor principal por excelencia de este tipo de imágenes solía ser el zorro y, tras él, el simio. En torno a las habilidades médicas del zorro, que Varty remonta hasta Esopo, gira uno de los episodios del Roman de Renart ${ }^{97}$ y su eco se percibe en los tantas veces mencionados Disparates muy graciosos: vi una zorra aprendiendo / para físico en Boloña ${ }^{98}$. En otras ocasiones el animal médico es un asno ${ }^{99}$, sin embargo, en esta imagen, tanto la complexión del animal que sostiene la redoma como su hocico achatado y su cola corta y enroscada permiten identificarlo como un cerdo. Maeterlinck respecto de imágenes análogas de los siglos XIII y xIV por él estudiadas afirma que lo que hace el animal es examinar la orina del paciente contenida en la redoma e interpreta todas estas imágenes, que, como tantas otras, perviven en los grabados populares, como una divertida sátira de los médicos ${ }^{100}$, aunque personalmente prefiero ver en ellas un aspecto más de ese inquietante mundo al revés a cuyo mejor conocimiento en un campo específico poco explorado de las artes figurativas de finales de la Edad Media he pretendido contribuir con estas líneas.

97 Varty, Kenneth: Reynard..., pp. 68-75.

98 Cancionero de obras de burlas..., p. 270.

99 Randall, Lilian M. C.: Images..., fig. 63.

100 Maeterlinck, L.: Le genre satirique..., p. 64. 